\title{
THE IRRIGATION QUESTION IN CALIFORNIA.
}

The economic future of the far west is largely dependent on a practical solution of the problem of irrigation. Millions of acres lie there sterile and lifeless, yet with all the elements of fertility locked up in the soil, and with a sunshine and a climate favorable to every kind of agricultural production. The nimble jugglery of the statistician does not enable one to grasp the situation. Square acres of maps and huge columns of figures convey but a dim impression of the urgency of the problem. Only the traveler who has passed over the vast solitudes and witnessed the transformation wrought here and there by some unknown Aaron of the wilderness, can appreciate the enormous forces of nature waiting for a deliverer. From the earliest settlement of the arid states of the West it was apparent that the question of water rights could not be left to the old rules of the common law. They were not adequate to the exigency. Their customs were crystallized into rigid rules in a land and a time when the permanent diversion of the water of a stream to irrigate the land of riparian owners for the purposes of cultivation was not required. In the far west on the contrary, the land is to a large extent valueless without the annexed right to appropriate water for the growth of crops. But the water is limited in amount while the irrigable area is almost illimitable, and the unguarded right of appropriation in one deprived another of the use of his property. The question forced itself at once into the domain of public regulation. Various complex codes sprang into existence having for their object the reconciliation of conflicting private interests and the greatest possible utility to the irrigable territories of all possible sources of water. So far as these laws provided for the regulation of private rights alone they were not sufficient; laws allowing the absolute ownership of water by an individual very often sacrificed the subsequent public welfare and the just rights of future settlers for the sake of a definite adjudication of title. Laws which allowed the proprietorship of water only to the actual occupant and cultivator of land, prevented the formation of companies to disperse the water over large areas. In States where 
the old substratum of the common law underlay the subsequent statutory enactment, satisfactory decision of some complex problems could not be obtained. In California no one has ever been able to determine how much water a subsequent proprietor settling on the stream above a prior settler, could use for irrigation without entrenching on the rights of the lower owner. The Supreme Court, in a decision ${ }^{1}$ some two hundred pages long, finally held that he could use as much as was necessary to cultivate the land provided he did not so divert the water as to materially injure his neighbor. The rule raised a very mixed question of law and fact as to what diversion was a "material" injury, and only added to the confusion already existent.

The dominant fact in the comprehension or settlement of the irrigation question is the incapacity of the individual to deal successfully with the problem and the consequent failure of laws acting on the individual alone to solve it. The settlers of the West were generally poor and their successors have limited capital. On the other hand the irrigation of arid lands of any locality very often require the construction on a great scale of works for the imprisonment and dispersion of the water. Dams have often to be driven down scores of feet through drift gravel to collect the percolating waters of sunken rivers, or tunnels to be driven through a great wall of rock to intercept the mountain flood. Subsidiary reservoirs are often required to subdivide the waters, canals lined with concrete and many miles long to be dug-power houses to force the reluctant tide to the point of ultimate dispersion. The work and capital required to supply one land owner with water often suffice to supply a hundred with the same facilities. The cost of such enterprises, even where of modest dimensions, is practically prohibitive to the individual irrigator, although the relative cost to each of the farmers of the community might be small. The power of organized capital is required and the coöperated support of the community. Such capital must be sought most often beyond the locality and frequently beyond the State. Private corporations to monopolize and hire out the water have been accordingly largely the means by which the arid tracts of the West have been made capable of cultivation. In favorable localities they have operated with some success. But there are many grave objections to leaving the question to private capital. Where it divorces the ownership of the water from the land, friction arises between the company and

1 Lux v. Haggin, 69 Cal. 
the irrigators. The cultivator suspects that he is robbed, as very likely he may be-and resents the " tyranny" of dues. Granger legislation is passed fixing rates ${ }^{2}$ and harrassing or throttling capital. Such companies are also often involved in a mesh of litigation which heavily increases its charges. The sources of water are so valuable and conflicting titles are so easily born of the vague claims of early occupants, that vexatious litigation, and ruin very often attends the attempted appropriation or purchase of a water right. The same difficulties increased by internal dissentions very often attend the formation of stock companies by the cultivators. One result is that capital to develop water rights is not easily obtained in many sections of the great West, or it can be gotten only on exorbitant terms.

To secure the immense amount of capital required a ground work of unquestionable security for the investment must be obtained; to obtain a clear title to water rights the barnacles of conflicting claims must be cleared away and to secure the just and equitable distribution of the water for the greatest good of the greatest number, resort must be had to some degree of public regulation and control. A public corporation providing security for capital by the power of taxation, clearing titles by the exercise of the right of eminent domain can alone completely answer all the requirements of the problem. The legislature of California accordingly passed the Wright act in r887. The basal 1 ,rinciple of this act was the division of the arid areas of the State into communities or districts whose limits were determined by their irrigability from the same common source of water supply and the same system of works. The admirable object of this act was to group productive communities around centers of water supply which would irrigate all the land within the district. The districts were, however, not attempted to be arbitrarily formed in the act, but were to be formed on the invitation of the people of the locality in accordance with the general provisions of the law instituted by a petition signed by the required number of freeholders and acted on by the Board of County Supervisors. ${ }^{3}$

So the great public powers of taxation and eminent domain are united with home rule as to the extent of debt incurred and the details of management. It is the general testimony of all

2 This is done in Wyoming.

3 For a sketch of the essential provisions of the act the reader is referred to Bradley v. Fallbrook. Irr. Dis. 68, Fed. Rep. 948; the Yale Law Journal

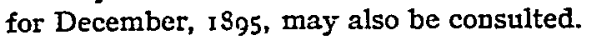


who are familiar with the situation in California that the act has been eminently successful in attaining the reclamation of a very large area of arid land which private capital would in all iikelihood never have developed. Many millions of dollars have been invested in the municipal bonds of the various districts and the prosperity of many sections of the State has largely increased through its operation. The exercise of the power of taxation by the district government and the consequent sales of land within the district for delinquent assessments against the consent of the owners led to bitter assaults on the validity of the act. The arbitrary incorporation of whole cities and towns within the districts by the Boards of Supervisors has lent fuel to the fire. The high valuation of the improved property of these municipalities largely lighten the burden to the farmer tax payer within the same district. Each land owner is entitled to receive a share of the water for irrigation purposes in proportion to his assessment, and, theoretically, he receives his benefits in the sale of his share in case he does not wish to use it. But the acquisition of a large supply of water for "irrigation" purposes by the owner of a dry goods "emporium" in the middle of a city is a somewhat inadequate return for his tax."

As a consequence the validity of the act under which these district corporations were organized and the constitutionality of their exercise of the power of taxation was brought before the Supreme Court of California in five different cases." A large number of technical objections were raised in all these cases attacking the acts of the district officials on the ground that the requirements of the act itself were not complied with; but so far as these objections do not assail the constitutionality of the act under which they were formed they are passed over. ${ }^{6}$

The Supreme Court of California uniformly overruled these objections and upheld the validity of the law as constitutional on reasons largely of public policy. The law was regarded as firmly established in view of the affirmation by the Supreme Court of

- Real property is required to be listed by statute at its full cash value, including improvements.

5 Turlock Irrigation Dist. $\nu$. Williams, $76 \mathrm{Cal}$. 360; Central Irrigation District $v$. De Koppe, 79 Cal. 35I ; Crall v. Poso Irrigation Dist., 87 Cal. 140; Board of Directors $v$. Tregea, 88 Cal. 334; In Re Madera Irrigation District, 92 Cal. 307.

- Numerous questions were raised impeaching the constitutionality of the act under the peculiar provisions of the Constitution of California affecting municipal corporations. None of these objections have solidity. For a discussion of them, see $I n \operatorname{Re}$ Madera, etc., $92 \mathrm{Cal}$. 307. 
the United States of the constitutionality of the reclamation districts which were public district corporations formed to drain swamp and overflowed lands. ${ }^{7}$

The opinion of Judge Ross in July last, ${ }^{8}$ rendered in the Circuit Court for the Southern District of California, practically upholding the vital objections raised before the Supreme Court of California in the cases cited fell like a thunder bolt from the clear heaven, staggering investors and invalidating all the bonds issued under the act. ${ }^{9}$ The reasons advanced by Judge Ross for holding the exercise of the power of taxation by the district authorities invalid divides into two great branches. It is asserted in the first place that the private property of the citizen cannot be taken for the benefit of a limited class in the taxing district to the exclusion of the remainder of the community: That the use to which the funds exacted by the power of taxation is devoted must be open to all the members of the taxing district on equal terms and conditions and that the exercise of taxation in the specific case at bar is for the benefit of the land owner of the district alone, and that this use is accordingly a private one and not for the benefit of the public at large, and that any incidental benefit which the State may derive no matter how important or extensive does not and cannot make a private use a public one. ${ }^{10}$

${ }^{7}$ Hagar v. Reclamation Dist., III U. S. zor, wherein it is said by Mr. Justice Field: "It is not open to doubt that it is in the power of the State to require local improvements to be made, which are essential to the health and prosperity of any community within its borders. To this end it may provide for the construction of canals for draining marshy and malarious districts and of levees to prevent inundations, as well as for the opening of streets and of roads in the country." (Not italicized in original).

${ }^{8}$ Bradley $v$. Fallbrook Irri. Dist., 68 Fed. Rep. 948.

9 The Bondholders would not of course be entirely without remedy in case the districts should refuse to pay the bonds, or were unable to do so because taxpayers availed themselves of the principles.laid down in the decision. They might, of course, follow the proceeds of the bonds, in equity, and seize on the works constructed with them. This would involve a change of security.

10 The case in point was a suit in equity to enjoin the execution of a deed of certain land of the complainant given by the collector of the defendant irrigation district under a sale to satisfy a delinquent assessment against his property, and the argument proceeds on the ground that such an enforcement of the assessment by the district officials with certain provisions of the constitution of the U. S., which declares that no person shall be deprived of his property without due process of law, and that the act provided for the taking of private property for private use, the decision proceeds: "It is the purpose and use of a work which determines its character. Streets and highways are in their routine public; for the very purpose of their construction is the 
This contention strikes at the very root of the question-what are the constituent elements of a public corporation? and what is the public use for which the power of taxation may be exercised? Can any ultimate increase in the general prosperity of all the citizens of a community justify the imposition of an assessment for the proximate benefit of a class even where the incidence of the assessment is limited to the class immediately benefited? In other words, can no great public improvement be wrought because the immediate effect of it be to benefit a specific class? It is apparent from a close examination of the cases in which the power of taxation by local boards has been upheld that a square negative to this question cannot be maintained. The power of taxation or of enforced assessments is habitually exercised for the benefit of a class which may be more or less numerous but clearly distinguishable from the great class of the people of a municipality. A schoolhouse located in a defined subdivision of a city for the benefit of the residents of that subdivision benefits only those who have

accommodation of the public to the use of which every person is entitled upon the same terms and conditions as every other person. Water appropriated or designed for the use of cities and towns becomes charged with a public use; for the very purpose of such appropriation is the supplying of the public with their necessary element, and every person within such cities and towns is entitled, or is on precisely the same terms and conditions. So, also, in dry and arid regions like many and great sections of California where water is their very life blood, is water appropriated or designed for the use of the public for purposes of irrigation. But can this properly be said in respect of a district however extensive its boundaries, when only certain persons are entitled to enjoy its use-that is to say, where only the land owners in the district are entitled to the use? Such land owners may be many in number or they may be few. It is manifest, however, that the character of the use is not to be vested by the mere number of persons who may enjoy it. No man's property can be constitutionally taken from him without his consent and transferred to certain other men for their use, however numerous they may be, and that is just what the legislation in question authorizes to be done. Private property is thereby authorized to be assessed and sold to provide water to supply the land owners in a certain district more or less limited in extent for irrigation purposes. Every person within such district is not entitled to the use of the water so provided upon the same terms and conditions as every other person, but only those persons who happen to own land in the district; of course the property of those individuals would thereby be improved, and indrectly the public good be thereby advanced. But every improvement advances the public good, every enterprise, no matter how strictly private it may be, if it be lawful and adds to the health, comfort and happiness of the people, is for the public good. The building of a house, or the planting of a useful or beautiful tree is for the public good. But surely private property cannot be taken against the owner's consent on the ground that the public interest would be thus promoted." 
children to send, but property owners are not relieved from taxation because they have no children. The benefit to the public at large requires the sacrifice of the individual who receives only the indirect benefit of the general welfare. Enforced assessments upon the land owners of a district formed to drain swamp or overflowed lands have been supported as an exercise of a public power of taxation not alone on sanitary grounds but on the broader grounds of the public welfare." Assessment districts for the construction of levees to prevent inundation may be referred to the police power to protect life and property, but they are justified in the decisions on the ground of a general public improvement. It is even impliedly admitted in the decision itself that the territory to be irrigated may be so extensive as to justify the construction of works at public expense for the benefit of coming settlers, provided each may use the water on the same conditions as any other. ${ }^{12}$ But can it be said that it is legitimate to tax the people of the whole State for the benefit of a section, but that it is not legitimate to accomplish the same purpose by dividing the same section up into districts and compelling the cost of the irrigation to be borne by the people whom it directly benefits instead of by the people of the State at large? It seems apparent that if the entire people of a State

11 Hagar v. Board, etc., 47 Cal. U. S. 222 it was said: "But we need not rest our decision on the narrow ground that this is strictly a local improvement. On the contrary the reclamation of the vast bodies of swamp and overflowed land in this State may justly be regarded as a public improvement of great magnitude and of utmost importance to the community. If left wholly to individual enterprise it would probably never be accomplished." And in Irrigation District $v$. Cultivators, $76 \mathrm{Cal} .368$, it was said: "The results to be derived from a drainage law and one which has for its purpose the irrigation of immense bodies of arid lands must necessarily be the same as respects the public good; the one is intended to bring into cultivation and make productive a large acreage of land which would otherwise remain uncultivated and unproductive of any advantage to the State, being useless, incapable of yielding any revenue of importance toward the support of the general purposes of State Government by reason of too much water flowing over, or standing upon, or percolating through them. The other has for its main object the utilizing and improvement of vast tracts of arid and unfruitful soil, desert-like in character, much of it, which if water in sufficient quantity can be conducted upon and applied to it, may be made to produce the same results as flow from the drainage of large bodies of swamp and overflowed lands."

12 "The scope of the legislation under consideration is not limited to cases where the territory designed to be supplied with water for irrigation is so extensive as to assume the importance of a public undertaking and where thus provided, the water is available to every person within the district upon the same terms and conditions." (At page 960 ). 
may be taxed for a local improvement which can only immediately benefit the class who reside there, the same affect may be attained by taxing the beneficiaries only; at most only a land owner can obtain the direct benefit of irrigation works, and the construction of any system whatever by the people of the State would be for the immediate benefit only of those who purchased the land. Either the State can undertake no system of irrigation at all, or taxation for the proximate benefit of the irrigator must be found to be constitutional, on the ground that the prosperity of the State is absolutely dependent upon it. $^{13}$ From time immemorial the power of public taxation has been exercised not only to develop the land of a State but to enable the owners of it to enjoy their property. The running of surveys, the building of roads, draining canals, etc., have been undertaken not primarily that all the members of the community may enjoy these objects of

${ }_{13}$ Coster v. Tidewater Co. 18 N. J., Eq. p. 54 ; same case, p. $53 \mathrm{r}$, throws an interesting light on the difference of opinion between even strict constructionists as to when the incidental public benefits from a local improvement may be so general as to justify the formation of a public corporation for its attainment. The case arose in equity on injunction proceedings against a corporation formed to clear a large area of swamp land in New Jersey of the water. None of the members of the corporation owned the land to be cleared, but the corporation was vested with right of eminent domain, and to charge the cost of the proceedings by assessment upon the owners. In chancery, Zabriskie chancellor ( 18 N. J. Eq. 54) held that the powers employed by the corporation of assessment, etc., could not be sustained, on the ground that the corporation was not formed to attain an object in which the public had a use, because the public "cannot use the meadows or the dykes, ditches, drains, culverts, pumps or machinery ; any stranger walking upon them" (the meadows evidently). "pasturing his horse, or cutting grass there would be a trespasser. No right is granted to any of the public." So far as the act was sustained at all it was on the ground of a public regulation of private property as a sort of quasi party wall (see infra discussion of Judge Ross' second objection). On appeal to the Court of Errors, however Beasley, C. J., also a strict constructionist, said, upholding the use as a public one (I8 N. J., Eq. 53I), "That the legisiative authority is competent to effect the end provided for in this act I can entertain no doubt. The purpose contemplated is to retain and bring into use a tract of land covering about one-fourth of the county of Hudson and several thousand acres in the county of Union. This large district is now comparatively useless. In its present condition it impairs very materially the benefits which naturally belong to the adjacency of the territory of the State to the navigable waters. It is difficult from the great expense of such works to build roads across it and consequently it has heretofore interposed a barrier to anything like easy access except by means of railroads from one town to another situated upon its borders. To remove these evils and to make this vast region fit for habitation and use seems to me plainly within the legitimate province of legislation and to affect such ends $I$ see no reason to doubt that both the prerogatives of taxation and of eminent domain may be resorted to." 
public expenditure, but that the contiguous land may be made productive, that the raw material of all wealth may be produced, and that as an indirect result population may be attracted and the objects of taxation may increase.

A very large area of the Western States is arid land. Any public measure for their irrigation will benefit only the land owners. "Any terms and conditions" on which "all" may enjoy the "right to use the water for the purpose of irrigation" can in any event be immediately enjoyed only by the land owners.

That a broad distinction exists between taxation for the development of land and for the protection of manufacturers is obvious. Without the land none can live. It lies at the base of all industry and material happiness. Every increase in the fertility of large areas powerfully affects every class of industry, while the extinction of the fertility of the land wipes out civilization itself. The imposition of a protective tariff enables a class - the manufacturer-to charge more for the article he produces than he otherwise could. But the exercise of taxation to irrigate land is primarily to make the State itself inhabitable; not primarily to benefit the land owner considered as a class but to prepare the land itself, the common source of all wealth, to support successive generations and form the foundation stone of a splendid civilization.

Can it be claimed that the national government would have no authority to appropriate money to reclaim a barren desert in its midst whose domain might be sufficient for the construction of many States? and that it could not tax all the people to so provide homes for the overflowing population? In every nation where systems of irrigation have been required, the subject has overleaped the limits of private right into the great domain of public regulation and control requiring a unitary system and constantly tending toward the exercise of eminent domain and public taxation. ${ }^{14}$

"As to the general power of the State to authorize such taxation, it was said in: In Re Madera, etc., 92 Cal., "If in the exercise of its care for the public welfare it finds that a specific district of the State needs legislation that is inapplicable to other parts of the State, it may in the absence of constitutional restrictions, legislate directly for that district; or if it be the case that similar legislation be required for other portions of the State it may provide for adopting such legislation or such portions at the will of the people in such districts as was done in the reclamation and levee laws already referred to. It may, too, by general laws authorize the inhabitants of any district under such restrictions and with such preliminary steps as it may deem proper to organize themselves into a public corporation for the purpose of exercising those 
The danger of this point of view is the confusion of a public use with a public "benefit." If the two are not kept sharply distinct there will be no bounds to the exercise of the'powers of

governmental duties upon the same principle as it authorized the incorporation of any municipal corporation under general laws," and in Board of Directors v. Tregea, $88 \mathrm{Cal}$. 334. it has said "whether the tax be by direct imposition for revenue or by assessment for a local improvement, it is based upon the theory that it is in return for the benefit received by the person who pays the tax or by the property which is assessed. For the purpose of apportioning this benefit the legislature may determine in advance what property will be benefited by designating the district within which it is to be collected, as well as the property upon which it is to be imposed; or it may appoint a commission $o_{I}$ delegate to a subordinate agency the power to ascertain the extent of this benefit. It may itself declare that the entire State is benefited and authorize the burden to be borne by a public tax; or it may declare that all or a portion of the property within a limited region is benefited, either according to its value, or in proportion to its actual benefit to be specifically ascertained by the actual determination of officers appointed therefor. It is not necessary to show that the property within the district may be actually benefited by the local improvements, and even if it positively appears that no benefit is received, such property is not thereby exempted from bearing its portion of the assessment, nor is the act unconstitutional because it provides that such property shall be assessed. Property that is exempt from taxation has always been held subject to the burdens of assessment for local improvements and property within a district that is not susceptible of receiving any immediate benefit from the improvement is nevertheless so indirectly benefited thereby, that it must bear a portion of the burden. If within the limits of a levee district a parcel of land should be so situated as not to require the protection of the levee, that would be no reason for excluding it from its share of the expense, or if within the limits of the drainage district there should chance to be found a cliff that would be no reason for exempting it from assessment." In Hagar $v$. Board, etc., $47 \mathrm{Cal} .222$, it was said: "The authority to compel local improvements at the expense of those to be immediately benefited is not taxation, though referable to the taxing power. It has never been held that taxation for general purposes or for local improvements is an infringement of that clause of the constitution relating to the acquisition and enjoyment of property tax, nor does the enforcement of a valid tax by whatever method constitute a taking of property without due process of law in the sense of the constitution, nor is it a taking of private property for public use within the purview of that instrument." And in Hagar $\%$. Reclamation Dist., III U. S. 705, by Justice Field it was said: "The expense of such works may be charged against parties specially benefited and be made a lien upon their property. All that is required in such cases is that the charges shall be apportioned in some just and reasonable mode according to the benefits received. Absolute equality in imposing them may not be reached. only an approximation to it may be attainable. If no direct and insidious discriminations in favor of certain persons to the prejudice of others be made, it is not a valid objection to the mode pursued that to some extent inequalities may arise *** wherever a local improvement is authorized, it is for the legislature to prescribe the way in which the means to meet its cost shall be raised, whether by general taxation or by laying the burden upon the district specially benefited by the expenditure." 
taxation except such as may lie in the discretion of the legislature. The early notion of a public "use" under the common law was the right of each member of a community to enjoy a material thing as water, or a public park, purchased with the public funds. The growing necessities of a complex society and large population led to an extension of this notion of a public use to such objects as might be enjoyed by each member of a taxing district; and where large areas of the land of a state are to be reclaimed by drainage or irrigation the law makes a further extension and on grounds of necessity finds by construction the conception of public use satisfied by the possible ownership which each member of the community and successive generations may have therein. The land is fixed while the generations change. But this exception must be confined to the land and is justified only by its peculiar relation to the state. ${ }^{25}$

The second vital objection raised by the decision is that if the enforced assessment be referred to the peculiar power of the Legislature to establish regulations for the improvement of a common tract of land, owned in severalty and susceptible only of a joint improvement, at joint expense ${ }^{16}$ - no sufficient opportunity was afforded the land owner to contest the validity of the proceedings upon which the assessment was based. This legislative power is called, in the decision, "The powers of assessment for local improvement."

The terminology is misleading and the power defined by the Supreme Court must be clearly distinguished from the power of assessment enforced by a municipality upon the adjacent land

15 Nobody can obtain the use of the water on a city street except the real estate owner. Any member of the community may purchase a house on the street and obtain the benefit of the water on payment of the tax. So any individual may purchase land in an irrigation district and obtain the water on payment of the tax. Another more striking instance is the creation of supreme courts of appeal by the legislature at public expense under a constitution allowing a legislature to create a "supreme court and such inferior courts as they may see fit." Under such provisions the legislature may largely confine the right of appeal to the highest court to persons only whose controversies involve titles to real estate. The upshot of which is that other litigants are supplying taxes to create a supreme court for the immediate use of citizens having law suits involving such titles.

16 In Wurts $v$. Hoagland, II4 S. 6I3 it was called: "The power of the legislature to establish regulations by which adjoining lands held by various owners in severalty, and in the improvement of which all have a common interest, but which by reason of the peculiar natural condition of the whole tract cannot be improved or enjoyed by any of them without the concurrence of all, may be reclaimed and made useful at their joint common expense." 
owners for the construction of roads, sewers, etc. For this power springs from the power of taxation. ${ }^{17}$ It is according to the cases one aspect of this supreme legislative power over the property of the citizen. But how can a forced assessment be exercised by members of a class for their private use? If referable to the power of taxation it can be exercised only for a public use which determines the limit of the taxing power. Nor is it the power of eminent domain, for that power is based upon full compensation to the citizen for the property taken, and where the assessment exceeds the benefit received it involves to that extent a condemnation of the surplus without compensation. It is, therefore, neither an exercise of the power of taxation, assessment for local improvement as usually understood, nor of eminent domain. It is an anomalous principle in the law of property rights. It has its origin in ancient usage and is analogous to the principle which requires the joint tenants of a party wall to share the expense of its repair. The principle was first clearly enunciated by the Supreme Court of the United States in construing a Mill Act, which allowed a land owner to erect and use a mill on a non-navigable river upon paying the adjacent owner damages for the overflow and it was said by the court in upholding the constitutionality of the act. ${ }^{18}$

"The question whether the erection and maintenance of mills for manufacturing purposes under a general mill act of which any owner of land upon a stream not navigable may avail himself at will can be upheld as a taking by delegation of the right of eminent domain of private property for public use in the constitutional sense is so important and far reaching that it does not become this Court to express an opinion upon it, when not required for the determination of the rights of the parties before it. We prefer to rest the decision of this case upon the ground that such a statute considered as regulating the manner in which the rights

17 State $v$. Fuller, 34 N. J., L. 227. So in in re Madera 92 Cal. It was said "while it is held that an apportionment of the expenses for a local improvement is to be made according to its benefits received by the property assessed, yet the power to make such apportionment rests upon the general power of taxation and the apportionment itself does not depend upon the fact of local benefit in any other sense than that all taxes are supposed to be based upon the benefit received by the tax payer. The benefit is not the source of the power." So the legislature may designate the district which will be benefited by the improvements, Diggins $v$. Brown, $76 \mathrm{Cal}$. 318, or by commissioners appointed to make specific assessments upon the several parcels of land. Pacific B. Co. v. Kirkham, 64 Cal. 519 ; Keese v. City of Denver, ro Colo. 13.

${ }_{18}$ In Herd v. Amoskeag Mfg. Co., 113 U. S. 20. 
of proprietors of land adjacent to a stream may be asserted and enjoyed with a due regard to the interests of all and to the public good is within the constitutional power of the Legislature. When property in which several persons have a common interest cannot be fully and beneficially enjoyed in its existing conditions the law often provides a way in which they may compel one another to submit to measures necessary to secure its beneficial enjoyment, making equitable compensation to any whose control of an interest in the property is thereby modified." 19

The origin of this distinction appears to lie deep down in the vitals of the principle that holders of property are under mutual obligation not to use their property so as to injure another, and that a refusal to join in an improvement required for the common utilization of common privileges is an injustice which the law will not suffer. It is a somewhat forced construction to bring the Wright Act with its great machinery of artificial conditions under the scope of this principle.

It is, however, essential to the second vital objection raised that the act must be brought under this principle. For his contention is that as the act vests no authority in the Board of Supervisors to "hear" objections to the petition, or a contest as to its compliance with the statutory requisites of signature by a required number of freeholders. ${ }^{20}$

19 After considerable conflict and wabbling in the cases, the New Jersey acts providing for the drainage of swamp lands and the assessment of the cost upon the land owners is upheld, not as an exercise of the right of taxation for a public use or eminent domain as held in In Re Lower Chatham $35, \mathrm{~N}$. J. L. jor, and many other cases, but as based on ancient use and analogous to party walls. Such corporations are not public corporations, nor are the assessments enforced referable to power of taxation or eminent domain.

In Re Pequest Rives, 4 I N. J. L. 175.

20 The argument of the decision proceeds:

"Not only does the legislation in question provide for the assessing and selling and thus for the taking of private property, in order to supply water for irrigation to specific persons within the district and to those only, but all of this is authorized to be done without affording the owner any opportunity to be heard in opposition to the validity of the proceedings. As has been seen, the act provides as a condition precedent to the organization of the district, the presentation to the Board of Supervisors of the county in which the lands or the greater portion thereof are situated, at a regular meeting of such board, of a petition signed by fifty or a majority of the holders of title or evidence of title to lands susceptible of one mode of irrigation from a common source and by the same system of works as shown by the equalized county assessment roll next preceding the presentation of the petition. which petition shall specifically describe the proposed boundaries of the district and ask that it be organized under the provision of the act. The Supreme Court 
of California said in the Madera Irrigation case, $92 \mathrm{Cal}, 323$, in answer to the present objection to the act that the proceeding for the organization of the district 'does not affect the property of any one within the district, and that he is not by virtue thereof deprived of any property. Such result does not arise until after the delinquency on his part in the payment of an assessment that may be levied upon his property, and before that time he has opportunity to be heard as to the correctness of the valuation which is placed upon his property, and made the basis of his assessment. He does not, it is true, have any ofportunity to be heard otherwise than by his vote in determining the amount of bonds to be issued or the rate of assessment with which they are to be paid; but in this particular he is in the same condition as is the inhabitant of any municipal organization which incurs a bonded indebtedness or levies a tax for its payment. His property is not taken from him without due process of law, if he is allowed a hearing at any time before the lien of assessment thereon becomes final.' A hearing as to what? The only hearing provided for by the statute is as to the correctness of the valuation put by the assessor upon the property assessed. Nor can I at all agree that the proceeding for the organization of the district 'does not affect the property of any one within the district.' The petition for the organization of the district was the foundation of the whole proceeding. - Without the required petition no step could be taken looking to the organization of the district here in question. It has jurisdictional in the strictest sense. Two weeks' notice of the time of presentation of the petition is required to be given by publication when presented, the statute declares the board of supervisors shall hear the same and may adjourn such hearing from time to time not exceeding four weeks in all, and, on the final hearing may make such changes in the proposed boundaries as they may find to be proper, and shall establish and define such boundaries; provided, that said board shall not modify said boundaries so as to except from the operation of this act any territory within the boundaries of the district proposed by said petitioners which is susceptible of irrigation by the same system of works applicable to other lands in said proposed district, nor shall any of the lands which will not in the judgment of said board be benefited by irrigation by said system, be included within such district; provided that any person whose lands are susceptible of irrigation from the same source may in the discretion of the board upon application in writing to said board have such lands included in such district. Notwithstanding the fact that the petition is by the statute made the basis of the proceeding which is to culminate in diverting the title of the owner of land against his consent, there is here not only no opportunity afforded such owner to test the sufficiency of the petition, for the power of the board of supervisors is in terms limited to making such changes in the boundaries proposed by the petitioners as it may deem proper subject to the condition that it shall not except from the operation of the act any territory within the boundaries proposed by the petitioners, which is susceptible of irrigation by the same system of work applicable to the other lands in said proposed district, nor include within the boundaries which it is required to establish and define within four weeks after the presentation of the petitioners, any lands which, in its judgment will not be benefited by irrigation by the same system of works. Every one must admit that in the matter in question the Board of Supervisors has only such power as is expressly or by necessary implication conferred upon it by the statute itself. Not only is it not thereby given the power to inquire into the sufficiency of the petition, but the express statutory require- 
ments preclude any such inquiry by it at the instance of any owner of land adversely affected if at all. Yet the petition may not have been signed by the required number of holders of title or evidence of title to lands within the districts, and if not, there was then no basis upon which the proceedings could rest. Whatever construction might otherwise be placed upon the word 'hear' used in the statute, it cannot be held to include the power to determine the entire merits of the petition in view of the affirmative requirement contained in the same sentence that on its final hearing the board 'shall establish and define such boundaries.' The Board is of necessity required to determine for itself whether the petition upon its face is sufficient to put its powers into motion; yet its determination in that respect is not conclusive upon anyone. Had it been impowered to entertain a contest, for example, by a land owner in respect to the question whether those signing the petition were, in truth, the holders of title or evidence of title to lands susceptible of one mode of irrigation from a common source and by the same system of works, and it should find in favor of the contestant upon that issue, it would necessarily be obliged to deny the petition and dismiss the proceedings. Yet so far from that course being allowed by the statute, it provides, as has been seen, that the Board of Supervisors shall hear the petition, and may adjourn such hearing from time to time, not exceeding four weeks in all, and, in express terms, declares that on the final hearing of such petition it may make such changes in the proposed boundaries as it may find to be proper and shall establish and define such boundaries. After the Board of Supervision shall have so established and defined the boundaries of the proposed district, and shall have divideu it into divisions, the Board is by the statute required to give notice of an election to be held in such proposed district for the purpose of determining whether or not the same shall be organized under the provisions of the act. The notice is required to describe the boundaries so established, and to designate a name for such proposed district. In the event two-thirds of the votes cast at such election are in the affirmative, the Board of Supervisors is by the statute required to declare, by an order entered on its minutes such territory duly organized as an irrigation district under the name and style heretofore designated, and to declare the persons receiving respectively the highest number of votes for the several offices to be duly elected thereto, and to cause a certified copy of such order to be immediately filed for record in the office of the connty recorder of each county in which any portion of such land is situated; and to mail immediately forward a copy thereof to the clerk of the board of supervisors of each of the counties in which any portion of the district may lie. And the statute declares that from and after the date of such filing the organization of such district shall be complete, and the officers thereof shall hold their respective offices until their successors are elected and qualified. The organization of the district is thus completed according to the statute. without at any time or place affording the owner of any land within the boundaries of the district the opportunity to question or contest the sufficiency of the petition which lay at the foundation of the whole proceedings. From first to last at no time or place is the owner of land within the district given the opportunity to be heard in respect to the essential and all-important question whether the petition upon which all the proceedings rest, and under which his property is to be assessed, sold and conveyed, conforms to the requirement of the statute; whether or not, it is in fact, signed by fifty or a majority of the holders of title or evidence of title to lands within the district, 
as shown by the last equalized assessment roll immediately preceding the presentation of the petition. Without such a petition as has been said no step could be taken looking to the organization of the district, (Milligan $v$. Smith, 59 Cal. 206, Zeigler $v$. Hopkins, I 7 U. S. 688, 6 Sup. Ct. 9I9) and of course without a legally organized district there can be no such thing as assessment. To say, therefore, as did the Supreme Court of California in the Madera Irrigation case that the land owner ' has opportunity to be heard as to the correctness of the valuation which is placed upon his property and made the basis of his assessment, does not at all answer the objection. So that, under the provisions of the statute in question, the land of an individual may be assessed and sold, and, according to the averments of the bill will, unless the court intervenes, be conveyed and thus taken, withont affording its owner any opportunity whatever to question the sufficiency of the petition upon which the whole proceedings are based. That this would be to deprive such owner of his property without due process of law, would seem to be very clear, in judging what is 'due process of law:' Said the Supreme Court of the U. S. in Hagar $v$. Reclamation Dist., IrI U.S. 708, 4 Sup. Ct 663: 'Respect must be had to the cause and object of the taking, whether under the taxing power, the power of eminent domain, or the power of assessment for local improvement, or some of these; and, if found to be suitable or admissible in the special case, it will be adjudged to be due process of law, but, if found to be arbitrary, oppressive and unjust, it may be declared to be due process of law. Assessments in California for the purpose of reclaiming overflowed and swamp lands to which the Supreme court of California in the cases cited likened to the irrigation districts are enforced by suits in which, as held by the Supreme Court of the United States in Hagar $v$. Reclamation Dist., Supra, the owner may set up by way of defense, all bis objections to the validity of the proceedings, and he is, therefore, in such proceedings afforded 'due process of law.' In the present case, however, as has been shown, the owner whose property is authorized to be taken is not afforded any cpportunity whatever, at any time or place, before any board or tribunal, to question the sufficiency of the very thing which lies at the foundation of the whole proceedings. This trial objection to the legislation in question is in no manner answered by the fact that by a supplemental act of the legislature of California, approved MIarch 16,1889 ( 86 Cal. 1889, pp. $212,21_{3}$ ) the board of directors of any irrigation district is authorized to commence a special proceeding in a Superior Court of the County in which the lands or some portion thereof are situated in which after the publication of notice of the proceeding. any person interested may come in and contest the legality and validity of 'each and all of the proceedings for the organization of said district under the provisions of the said act, from and including the petition for the organization of the district, and all other proceedings which may affect the legality or validity of said bonds, and the order for the sale and the sale thereof.' Such a proceeding may or may not be instituted by the board of directors of the district, and was not instituted in the present instance so far as appears from the Bill. No man's constitutional rights can depend upon an option which may or may not be exercised by another."

Evidently if only the power of taxation is concerned no such "hearing" would be required. As the State may form a public corporation for a public purpose against the will of the citizen, and it would in this instance be of no vital importance, whether 
the petition was sufficient or not for the effective determinant in the formation of the corporation would be the two-third vote of the legal voters of the district, and since the corporation could be formed in any way the Legislature saw fit, the Legislature would have the discretionary power to make the initiatory proceedings of the petition merely formal, ${ }^{21}$ and the right of the citizen to be heard as to the justice of the assessment of his property would be satisfied by" the provision in the act for a hearing before the Board of Equalization. If, however, considered as a special proceeding to enforce a public regulation of private property the statutory requisites be considered jurisdictional, it does not appear that the citizen cannot question the sufficiency of the petition. The statute expressly asserts that they shall "hear" the petition and expressly allows them to adjourn for that purpose. How can the Board "hear" the petition and why should they publish a notice of the time and place where it is to be considered unless the citizen is to be granted an opportunity to appear and be heard. If the petition is jurisdictional as asserted, it would be absurd to argue that the statute compels the Board to proceed on a void petition. This would be to construe the statute to require all the machinery of act to be set in motion, although all the proceedings are void. A more commonsense interpretation of the statute would seem to give the word "shall" in the clause declaring that "A petition shall be presented * * * signed by the required number of holders of Title," equivalent force with the "shall" in the words "shall hear," and "shall proceed," and to hold that the statute requires the signature of the required numbers; that it does not provide for any other kind of a petition; that the supervisors must discover whether the act is complied with; and that the word "hear"

21 In Re Madera, $9_{2}$ Col. it was said: “ The steps provided for the organization of the district are only for the creation of a public corporation to be invested with certain political duties which it is to exercise in behalf of the state. It has never been held that the inhabitants of a district are entitled to notice and hearing upon a proposition to submit such question to a popular vote. In the absence of constitutional restriction it would be competent for the legislature to create such public corporations, even against the will of the inhabitants. It has as much power to create the district. $* *_{*}^{*}$ It must be observed that such proceeding does not affect the property of any one within the district, and that he is not by virtue thereof deprived of any property. Such result does not arise until after delinquency on bis part in the payment of an assessment that may be levied upon his property, and before that time he has opportunity to be heard as to the correctness of the valuation. which is placed upon his property, and made the cause of his assessment. 
implies a hearing of any and all objections, including those going to the sufficiency of the petition. As a matter of fact the practice is to hear objections. ${ }^{22}$

The decision of Judge Ross is strong but oblique. There is an evident failure to give a full consideration to the cases arising under the Reclamation Act upon whose outlines the Wright act is based, and in whose constitutionality the learned judge acquiesced as one of the Supreme Court of California. While the exercise of the taxing power authorized by the Act mav be found constitutional, ${ }^{23}$ many of its provisions may be justly criticised as too arbitrary.

The absolute power vested in the Board of Supervisors to include or exclude such lands practically as they see fit is capable of great abuse to the detriment of adjacent land owners. There should be a right of appeal to the Superior Court on the ground of an abuse of discretion. So under the amended Section Fifteen of the Act ${ }^{25}$ ostensibly providing for special elections to provide additional funds for construction purposes, a clause is slipped in allowing the directors to supply the money by assessment even if voters refuse to provide it, so practically placing in their power all the property of the district without any check or control whatever. Cities and towns should not be included without a majority vote of their citizens without reference to the vote of the remainder of the district. The debt which the district can incur should be limited to a reasonable proportion of the valuation of the property of the district.

A more stringent provision should also be adopted defining what sources of water may be sought for irrigation purposes. An act which allows all the land in the taxing district to be voted away to catch possible rain water, ${ }^{26}$ puts a premium on dishonesty and allows the great public power of taxation vested in trust in the district for the public welfare to be distorted for the benefit of $i$. speculators.

The tendency of such arbitrary and careless legislation is

22 Board of Directors $v$. 'Tregea at p. 355 .

As to various remedies open to a taxpayer who questions the sufficiency of the petition, see 9\% Cal. 334. This objection is also of minor importance because the act may be amended by the legislature so as to explicitly provide for a hearing.

${ }^{23}$ The Irrigation cases are now on appeal before the U. S. Supreme Court.

24 See Board of Directors $v$. Tregea, $88 \mathrm{Col}$. 354, where this power is declared final and conclusive beyond appeal.

${ }^{25}$ Laws Cal. 189I, page 147, Chap. CXX., viii.

${ }^{26}$ See Fallhook $v$. Bradley, Irr. Dis., 68 Fed. Rep. 948. 
undemocratic and unjust. Unfortunately legislation, depriving political subdivisions of the right to vote on the question of local improvements for which they are taxed, is on the increase. A law was recently introduced in the legislature of New York vesting in the supervisors of the county the right by an arbitrary vote to force taxation on the state, county and city. ${ }^{27}$ If this kind of statutory evolution goes on all the property in the country will be subject to the arbitrary power of "Boards"and sometimes very wooden ones-of minor officials who are often as ignorant as they are irresponsible; and the taxpayer might as well pay the full value of his property at once into the public treasury and live on such gratuities of provender as these petty magnates see fit to dole out to him.

William P. Aiken.

${ }^{27}$ A good-roads bill was put into the bill box by Senator Nussbaum (Rep., Albany) to-day. It provides that boards of supervisors of counties by a majority vote may improve public roads by laying down macadam, telford-macadam roads, or roads of other stone or concrete material. When a board of supervisors decides to improve the highways, a superintendent of roads shall be appointed who shall be a civil engineer and surveyor. Maps of roads are to be prepared by the superintendent and submitted to the board of supervisors and the State Engineer for approval. The superintendent's salary is to be a county charge and the costs of improvements are to be assessed as follows: I5 per cent on the town in which the improvements are to be made, or if in two or more towns a ratable assessment; 35 per cent on the county at large, and 50 per cent on the State."-N. Y. Ev. Post, Jan. 23, 1896. So the Good Roads Act of Connecticut taxes, at the instance of the vote of the town, both the county and the state. The state votes by the legislature, the town by its citizens, where does the county come in? 